\title{
The question of cost is irrelevant
}

\section{Jeff Adams}

The realisation that art education is of immense cultural value and needs protecting and sustaining was brought home to me by attending a conference recently organised by NSEAD and held at the Yorkshire Sculpture Park in England about the National Arts Education Archive (2015). The collection is more than an assemblage of artefacts; it is also representative of ways of thinking about art, and indeed education, ways that have much to do with the wider social struggles for voice, expression and active participation as young people learn to be citizens in a democracy. This is exemplified for me in a statement made by Herbert Read, a great advocate and collector of children's art himself, when discussing the construction and layout of schools as spaces for creative learning:

New schools will have to be built; our concern as educators is to see that they are practical embodiments of our new ideals. ... The question of cost is irrelevant: there is land, there are building materials, there is skill and labour. In a rational society, there is only the question of priority, and no services in such a society, save those nourishing and protecting life itself, should have priority over education. (Read 1943/1970 p. 301)

The belief, implicit in this pronouncement, of the fundamental importance of education to human culture and society, and with it the subordination of economics to state education, sounds quite extraordinary to us now. This is especially true for those of us in England defending the place of the arts in the education curriculum in an era of political thought defined by the ascendency of neoliberalism. What were once common philosophical ideals rooted in the confidence of an expanding democratic citizenship, might today be interpreted as reckless profligacy. Of course, Read's utterances reflect his own distinctive political sensibilities, a product of the extreme social conditions which he experienced in wartime Britain, yet they may still offer us a way of rethinking art education in our own benighted times.

I want to pursue this point because I believe that we have been hoodwinked by the 'common sense' of neoliberal philosophy that would have us believe that the arts should be reduced to a service in a competitive laissez-faire market. Mantras such as 
'value for money' have become the condition of all practical and intellectual endeavour, and the creative imperatives of children, as well as those of us who practise as educators and artists, are suffering the consequences, the most damaging of which is our inadvertent complicity in the concept of the arts-as-service. The arts in education have become marginalised and subordinated under this malign influence, which is plain enough to see in England, as in many other places (Adams \& Owens 2015).

It's important to acknowledge our complicity in our current plight, however. It may well prove to have been a mistake to attempt to accommodate neoliberal thinking by trading off of our principles in exchange for recognition and legitimacy. Nowhere is this more apparent than in our defence of the arts in the school curriculum on the basis of their value in servicing the economy or ameliorating social disadvantage; the following may serve as examples of this willingness to subordinate the arts in education:

National task force reports increasingly link the benefits of arts education to the changing demands on the workforce in the knowledge economy ... Arts integration models, the practice of teaching across classroom subjects in tandem with the arts, have been yielding some particularly promising results in school reform and closing the achievement gap. (President's Committee on the Arts and the Humanities 2011, p.38)

...schools that integrate arts across the curriculum in the US have shown consistently higher average reading and mathematics scores compared to similar schools that do not (Arts Council of England 2014, p.8).

Although these statements are well intentioned, and are borne of hope to legitimise the arts in education on the basis of their service value, they may actually achieve the reverse. As Earle (2015) explains:

The arts have a complex relationship with society, but arts lovers need to make a case for arts education that doesn't harness it to contemporary moral, civic, social or economic priorities. And we shouldn't resort to implying that without it people are likely to be stupid or more inclined to crime and immoral behaviour, or even that it makes people more employable. The Gradgrind 
mentality of relying on 'facts' - that is, 'evidence' that arts do good - allows little space for an intellectual consideration of the complexities of arts-based experiences.

The children learning to understand how their bodies can express friendship through dance, or grappling with drawing ideas and techniques, or getting excited about knocking out a makeshift love song, are not concerned with furthering the economic aims of businesses, corporations or the nation, and nor should they be. That they may never contribute in any realistic, practical sense to economic goals is of no consequence for any measure of their creative value to human society and culture, and to attempt to make them so may only serve to diminish their achievements. Whether these children eventually turn their creative expressions into lucrative careers or consign them to childhood explorations is not the point; the interaction between their idea, the medium and their audience, was an end (or a beginning) in itself, and a worthy one.

Adopting the essential premise of the centrality of the market to human society gives rise to further myths, each of which serves to shore up and sustain the other. The notion of 'core' subjects in the curriculum, is one such. This sustains the belief that some subjects are more important and have more worth than others, premised on their supposed economic contribution. This notion is conjured from the features assigned to favoured subjects, and creates a false inequality, from which an arbitrary hierarchy is established which has a number of common forms, each as insidious as the other. STEM subjects (Science, Technology, Engineering and Mathematics) and the proposed English Baccalaureate curriculum (DfE, 2015) are but two manifestations of this principle of segregating academic disciplines into unequal subjects (the unseemly struggle between those left out of STEM to be incorporated into it is indicative of the divisiveness of the concept, e.g. STEAM (+ Art); eSTEM (+ environmental); STREAM (+ Art and Religion); STEMM (+ Medicine); source: Wikipedia 2015).

Even where the arts appear in the curriculum they are increasingly in reductive forms that can readily be tested, placed in competition and ranked, and they are often instruments to demonstrate individual technical performance rather than collaborative or socially-orientated learning. In such regimes the assessment of arts subjects is principally one of 'criteria compliance' (Torrance, 2015), where the slavish imposition of predetermined criteria can only produce predictable and compliant performance, 
anathema to those creative practices that might be defined as experimental, imaginative and unpredictable (Adams \& Owens, 2015).

To get to the nub of this problem it is helpful to look at the work of Maclntyre (2007) who uses the concept of 'goods', which are the benefits or achievements to be derived from a practice, of which he defines two types: internal and external. External goods are those that are not specific to a practice, and could be achieved by means other than the practice itself; for example, an artwork could be made for the accumulation of money or to win a prize in a competition. Internal goods, on the other hand, are intrinsic to a practice, and can only be achieved through the knowledge and expertise specific to it. Moreover, they can only be judged and recognised in relation to that practice i.e. when an artist develops a new printing technique which is acknowledged by other printers.

The social consequences of these relative benefits are, for Maclntyre, not inconsiderable: for internal goods, 'their achievement is a good for the whole community who participate in the practice' (2007 pp. 190-191). In other words the value of a practice itself is increased through participants' increasing mastery and expertise, and this cannot diminish others' experience of that practice. The opposite is true for external goods, since they are essentially competitive, whereby the accumulation of wealth or material success by one participant in the practice (as 'winner', for instance) only serves to increase their personal advantage, at the expense of others.

A key word from Maclntyre is 'community': neo-liberal discourse is predicated on individualism, and the responsibility of the individual for their own fate. Shared, cooperative, communal endeavour is anathema to the market belief system, dependent as it is on a fragmented, atomised society in unequal competition with itself. The goods of the arts in education, emanating from their inherently communicative, social expressions, lie in the enrichment to the practices themselves, which need not be competitive nor in the service of others, but instead enrich the culture, whether that be in the school, or in the wider society. It is these features that we should fight to sustain, because practising the arts is synonymous with practising humanity, ergo 'the question of cost is irrelevant'. 


\section{References}

Adams, J. \& Owens, A. (2015) Creativity and Democracy in Education: Practices and Politics of Learning Through the Arts. London and New York: Routledge.

Arts Council of England (2014). The value of arts and culture to people and society: an evidence review. Available at: https://www.google.co.uk/search?q=arts+in+school+necessary+for+economic+gr owth\&ie=utf-8\&oe=utf-8\&gws_rd=cr\&ei=tkRcVojDBlqNasuzqJgM (accessed 30 November 2015)

DfE (Department for Education, UK) (2015) The English Baccalaureate. Available at: https://www.gov.uk/government/publications/english-baccalaureate-ebacc (accessed November 9 2015)

Earle, W. (2013) The importance of teaching the arts, Spiked (online, 20 August 2013). Available at http://www.spiked-

online.com/newsite/article/the_importance_of_teaching_the_arts/13937\#.VlwrcXv NzOU (accessed 30 November 2015)

National Arts Education Archive (2015) Available at: http://www.artsedarchive.org.uk/ (accessed 9 November 2015)

MacIntyre, A. (2007) After Virtue: A Study in Moral Theory. London: Gerald Duckworth.

President's Committee on the Arts and the Humanities (2011) Reinvesting in Arts Education: Winning America's Future Through Creative Schools (Washington, DC, May 2011). Available at: www.pcah.gov (accessed 30 November 2012) Read, H. (1943/1970) Education Through Art. London: Pantheon.

Torrance, H. (2015) Blaming the victim: assessment, examinations, and the responsibilisation of students and teachers in neo-liberal governance, Discourse: Studies In The Cultural Politics Of Education (online: published 30 October 2015). Available at: http://www.tandfonline.com/doi/full/10.1080/01596306.2015.1104854 (accessed 2 November 2015)

Wikipedia (2015) Science, Technology, Engineering, and Mathematics. Available at: https://en.wikipedia.org/wiki/Science,_Technology,_Engineering,_and_Mathemati cs (accessed 6 November 2015) 